\title{
SODIUM CITRATE PREMEDICATION IN ELECTIVE CAESAREAN SECTION PATIENTS*
}

\author{
David M. Dewan, W.D.R. Writer, A. Scott Wheeler, Francis M. James, III, \\ Herbert M. Floyd, Terrence D. Bogard and Leonard Rhyne.
}

AbstraCt

\begin{abstract}
The $\mathrm{pH}$ and volume of gastric contents from thirty-three patients undergoing elective caesarean section with thiopentone, nitrous oxide, succinylcholine anaesthesia were examined. Twenty patients received Gelusi $l^{\oplus} 30 \mathrm{ml}$ by mouth and thirteen patients received $30 \mathrm{ml}$ of a 0.15 molar solution of sodium citrate. Following tracheal intubation, gastric fluid was sampled through an 18 French Salem sump tube placed orally.

Mean $\mathrm{pH}$ following Gelusil ${ }^{\circledast}$ was $4.54 \pm 2.45$ (SD) and $2.29 \pm 1.77$ following sodium citrate. This difference was statistically different $(P<0.05)$. There was no difference in gastric volume between the two groups.

Thirty-five per cent of patients receiving Gelusil ${ }^{\otimes}$ had a $\mathrm{pH}<2.5$. This low $\mathrm{pH}$ was more likely to occur with prolonged intervals between drug administration and sampling. Significantly more patients receiving sodium citrate had a low $\mathrm{pH}$ (85 per cent) and this low $\mathrm{pH}$ was not related to the duration of interval between administration and sampling.

This study demonstrates that $30 \mathrm{ml}$ of 0.15 molar sodium citrate is not a satisfactory alternative to $30 \mathrm{ml}$ of Gelusil ${ }^{\text {to }}$ for increasing gastric $\mathrm{pH}$ in the parturient when given sixty minutes before operation.
\end{abstract}

Key Words: Premedication, antacid, sodium citrate; Surgery, caesarean section.

ASPIRATION of gastric contents remains a leading cause of anaesthetic-related maternal mortality. Forty-two per cent of maternal anaesthetic deaths reported in Great Britain in 1980 involved aspiration of gastric contents, and sixty-nine per cent of these deaths were typical of acid aspiration despite the use of prophylactic antacids in the currently "recommended amounts."

This apparent failure of antacid therapy supports the belief that antacids, although effective chemically, have not decreased the mortality rate from aspiration. Gibbs and coworkers ${ }^{2}$

David M. Dewan, M.D., Assistant Professor; W.D.R. Writer, M.B., Ch.B., Associate Professor and Research Fellow in Obstetrical Anaesthesia A. Scott Wheeler, M.D., Associate Professor; Francis M. James III, M.D., Professor; Herbert M. Floyd, Assistant Professor; Terence D. Bogard, Instructor; Department of Anaesthesia; Leonard Rhyne, Ph.D., Associate professor, Family Practice and Community Medicine; Wake Forest University, Bowman Gray School of Medicine, Forsyth Memorial Hospital, 3333 Silas Creek Parkway, Winston-Salem, North Carolina 27103 , U.S.A.

*Presented in part at the Annual Meeting, Canadian Anaesthetists' Society, Halifax, Nova Scotia, June 1981

Address reprint requests to Dr. D.M. Dewan. observed that antacids injected into the trachea of animals can produce severe pulmonary lesions whose duration exceeds that produced by acid itself and this may help to explain the failure of suspension antacids to decrease mortality. Clear solutions, buffered to the same $\mathrm{pH}$ as suspension antacids, do not produce pulmonary "antacid" lesions when injected into the trachea. ${ }^{2}$ For this reason sodium citrate, a clear solution, has been proposed as an alternative to the usual emulsified antacids. Consequently we examined the effectiveness of sodium citrate in healthy parturients presenting for elective caesarean section and compared it with that of the conventional antacid Gelusil ${ }^{(\mathbb{B})}$.*

\section{METhod}

The Clinical Research Practices Committee reviewed and approved the protocol. Thirtythree healthy term parturients with uncomplicated pregnancies scheduled for elective caesarean section under general anaesthesia were included

*Gelusil R - Warner Chilcott - each $5 \mathrm{ml}$ contains $200 \mathrm{mg}$ aluminum hydroxide, $200 \mathrm{mg}$ magnesium 355

Can. Anaesth. Soc. J., vol. 29, no. 4, July 1982 
TABLE I

Age, Weight and Premedication to Sampling Interval in Patients Given Gelusil and Sodium Citrate

\begin{tabular}{lccc}
\hline \hline & Gelusil $^{\text {(日) }}$ & Sodium citrate & Significance \\
\hline & $\mathrm{N}=20$ & $\mathrm{~N}=13$ & \\
Age (yrs) & $24.65 \pm 5.06$ & $27.07 \pm 5.89$ & N.S. \\
Weight (kg) & $75.75 \pm 30.57$ & $84.23 \pm 15.92$ & N.S. \\
Sampling interval min & $84.45 \pm 17$ & $81.0 \pm 17.1$ & N.S. \\
\hline
\end{tabular}

Mean \pm standard deviation.

TABLE II

Mean Gastric Volume and pH ( \pm S.D.) and InCidence (\%) OF Gastric $\mathrm{pH}<2.5$ in Patients Given GelusiL ${ }^{\oplus} 30 \mathrm{ml}$ and $0.15 \mathrm{M}$ Sodium Citrate $30 \mathrm{ml}$ BY MOUTH

\begin{tabular}{lccc}
\hline \hline & Gelusil & Sodium citrate & Significance \\
\hline & $\mathrm{N}=20$ & $\mathrm{~N}=13$ & \\
Volume & $36.55 \pm 22$ & $34.39 \pm 16.1$ & $\mathrm{~N} . \mathrm{S}$. \\
$\mathrm{pH}$ & $4.55 \pm 2.46$ & $2.29 \pm 1.77$ & $\mathrm{P}<.05$ \\
$\mathrm{pH}<2.5^{*}$ & $35 \%(7 / 20)$ & $84.6 \%(11 / 13)$ & $\mathrm{P}<.05$ \\
\hline
\end{tabular}

*Per cent of patients with gastric $\mathrm{pH}<2.5$ with $(\mathrm{N})$ representing number of affected patients per group.

in the study. Twenty patients received $30 \mathrm{ml}$ of Gelusil ${ }^{\otimes}$ orally and 13 others drank $30 \mathrm{ml}$ of 0.15 molar sodium citrate* approximately sixty minutes before operation. The patients were transferred to the operating room in the lateral position and placed on the operating table in a fifteen degree left lateral tilt. An intravenous infusion was started using lactated Ringer's solution and anaesthesia was induced with intravenous thiopentone $3 \mathrm{mg} \cdot \mathrm{kg}^{-1}$. Tracheal intubation followed an intravenous bolus of succinylcholine $1.2 \mathrm{mg} \cdot \mathrm{kg}^{-1}$ and anaesthetic maintenance consisted of nitrous oxide and oxygen (2:1) while a 0.1 per cent succinylcholine infusion provided muscle relaxation. As soon as possible following intubation we passed an \#18 Salem sump tube orally and emptied the stomach as completely as possible. The volume of each gastric specimen was measured and the $\mathrm{pH}$ was determined. $\dagger$ We compared the findings using the Student's $T$ test and the Fischer exact test, and considered $\mathrm{p}<0.05$ as significant.

*Sodium citrate solution represents $44.1 \mathrm{gm}$ sodium citrate dissolved in $1000 \mathrm{ml}$ aniseed flavored distilled water, $\mathrm{pH} 8.4$.

†Fischer Acumet pH Meter, Model 1212.

\section{RESULrs}

The patient groups were similar in age, weight, and interval between antacid administration and sampling (Table I).

Gastric volumes were similar in the two groups; however, the mean $\mathrm{pH}$ was lower in the sodium citrate group (Table II). Thirty-five per cent of patients receiving Gelusil had a pH less than 2.5 , whereas 85 per cent receiving sodium citrate had a $\mathrm{pH}$ less than 2.5 . This difference was statistically significant.

The lower $\mathrm{pH}$ values which occurred in the Gelusil ${ }^{3}$ group correlated with longer intervals between antacid administration and sampling. No patient sampled within 75 minutes of Gelusil $^{\oplus}$ administration had a $\mathrm{pH}$ less than 2.5. When sodium citrate was used, longer intervals were not associated with a lower $\mathrm{pH}$

\section{Discussion}

Our strongly negative results are both disappointing and somewhat surprising. Lahiri first examined the use of sodium citrate as an antacid in $1973 .{ }^{3} \mathrm{He}$ found its buffering capacity in vitro exceeded that of sodium bicarbonate and mag 
nesium trisilicate, with a duration of action exceeding 50 minutes. In a clinical trial, $15 \mathrm{ml}$ of 0.3 molar solution produced a $\mathrm{pH}$ greater than 3.0 in 21 of 22 parturients presenting for emergency operative procedures under general anaesthesia. By contrast, Hester and Heath found no decrease in the incidence of $\mathrm{pH}$ less than 2.5 when comparing sodium citrate to a control group. ${ }^{4}$ They did not examine mean $\mathrm{pH}$, but concluded that Lahiri's good results represented sample contamination.

Recent reports have not resolved the controversy. Foulkes, et al. ${ }^{5}$ and Abboud ${ }^{6}$ both found sodium citrate to be effective but used $30 \mathrm{ml}$ of 0.3 molar solution, a dose of antacid double that used in earlier reports. In addition, Abboud's patients received glycopyrrolate which also increases gastric $\mathrm{pH}$. Most recently Viegas, like Lahiri, successfully used the smaller $15 \mathrm{ml}$ volume of 0.3 molar sodium citrate. ${ }^{7}$ However his mean interval between drug administration and sampling was only fifteen minutes.

Several factors may explain the ineffectiveness of sodium citrate in our patients. The diluted solution of antacid used by our group, although $30 \mathrm{ml}$ in volume, was actually the same buffering capacity as that used by Lahiri and Hester and may be unreliable, as Hester suggested. The success noted by Foulkes and Abboud may have resulted from the larger volume of undiluted antacid used. Viegas' success with the smaller volume may reflect an interval between drug administration and sampling drastically shorter than ours. Perhaps a smaller dose provides a shorter period of effectiveness. A short duration of action has previously been demonstrated with magnesium trisilicate, but in this case would be at variance with the original in vitro findings of Lahiri which predicted a duration of at least fifty minutes. ${ }^{3}$ Gibbs' finding that, in vitro, the presence of homogenated gastric aspirates diminishes the effectiveness of sodium citrate may explain this discrepancy. ${ }^{9}$ Nevertheless our inability to correlate interval and $\mathrm{pH}$ remains unexplained.

Inadequate mixing of the antacid with gastric contents offers an additional explanation of our results. Holdsworth ${ }^{10}$ recommends turning patients from side to insure proper mixing of the antacid with the gastric contents. Radiographic studies have revealed that the stomach is divided into right and left pockets by the vertebral column when patients assume the supine position. It seems unlikely, however, that this should only effect the sodium citrate patient and not the Gelusil ${ }^{\oplus}$ patient.

Finally, our data did not reveal significant differences in gastric volumes between the two groups. A dye dilution technique would have been more accurate in estimating the gastric volume, but the same error should have been present in both patient groups. Our findings contrast with Foulkes, et al. ${ }^{5}$, who found larger gasric volumes when sodium citrate was used than in either control patients or when cimetidine was used. Further studies will be required to clarify this point.

We therefore conclude that since a $\mathrm{pH}$ of less than 2.5 has been implicated as a critical factor in determining the extent of pulmonary injury in aspiration pneumonia, $30 \mathrm{ml}$ of 0.15 sodium citrate does not represent a satisfactory alternative to Gelusil for increasing gastric $\mathrm{pH}$ in the parturient when given sixty minutes before operation.

\section{REFERENCES}

1. Morr, D. Maternal mortality and anaesthesia. Br. J. Anaesth. 52: 1 (1980)

2. GibBs, C.P., SChWartz, D.J., WynNe, J.W. et al. Antacid pulmonary aspiration in the dog. Anesthesiology 51: 380 (1979).

3. Lahiri, S.K., Thomas, T.A. \& Hodgson, R.H.M. Single dose antacid therapy for the prevention of Mendelson's syndrome. Br. J. Anaesth. 45: 1143 (1973).

4. Hester, J.B. \& Heath, M.L. Pulmonary acid syndrome: should prophylaxis be routine? Br. J. Anaesth. 49: 595 (1977).

5. FoulKes, E. \& JENKINS, L.C. A comparative evaluation of cimetidine and sodium citrate to decrease gastric acidity and effectiveness at the time of induction of anaesthesia. Can. Anaesth. Soc. J. 28: 29 (1981).

6. Abboud, T.K., Curtis, J.D., Earl, S., et al. A comparison of Gelusil and sodium citrate on gastric acidity. Abstracts of Scientific papers, Annual Meeting of the Society for Obstetric Anesthesia and Perinatology (1981).

7. Viegas, O.J., Ravindran, R.S. \& SchuMAKER, C.A. Gastric fluid $\mathrm{pH}$ in patients receiving sodium citrate. Anesth. Analg. 60 : $521(1980)$.

8. Hutchinson, B.R. \& Newson, A.J. Preoperative neutralization of gastric acidity. Anaesth. Intens. Care. 3: 198 (1975).

9. GibBS, C.P. In-vitro evaluation of sodium citrate as an antacid. Abstracts of Scientific Papers. Annual Meeting of the Society for Obstetric Anesthesia and Perinatology (1981).

10. Holdsworth, J.D., Johnson, K., Mascall, G., et al. Mixing of antacids with stomach contents. Anaesthesia 35: 641 (1980). 


\section{RÉSUME}

Nous avons déterminé le $\mathrm{pH}$ et le volume du liquide gastrique chez 35 parturientes accouchées par césarienne et anesthésiées au moyen de thiopentone, de succinylcholine et de protoxyde d'azote. Vingt des patientes avaient reçu $30 \mathrm{ml}$ de Gélusil ${ }^{\circledR}$ per os environ 60 minutes avant l'intervention; 13 autres patientes avaient reçu $30 \mathrm{ml}$ d'une solution 0.15 molaire de citrate de soude. Le liquide gastrique (aspiré après l'intubation des patientes) était de $4.54 \pm 2.45$ (SD) chez les patientes ayant reçu le Gélusil ${ }^{\circledast} \mathrm{et} \mathrm{de} 2.29 \pm 1.77 \mathrm{chez}$ celles ayant reçu la solution de citrate de soude $(p<0.05)$. Le volume moyen de ce liquide était le même dans les deux groupes.

Chez 35 pour cent des patientes ayant reçu le Gélusil ${ }^{\$ 8}$ on a trouvé un pH inférieur à 2.5 , ce qui était plus susceptible de se produire lorsque les intervalles entre l'administration du médicament et la mesure du $\mathrm{pH}$ étaient plus longs. Une proportion (85 pour cent) significativement plus élevée de patientes ayant reçu la solution de citrate de soude présentait un pH du liquide gastrique inférieur a 2.5 et ceci, sans égard à l'intervalle entre l'administration de l'agent et la mesure du $\mathrm{pH}$.

Ce travail démontre que l'administration de $30 \mathrm{ml}$ d'une solution 0.15 molaire de citrate de soude 60 minutes avant une césarienne ne constitue pas une alternative satisfaisante à une dose orale de Gélusil ${ }^{\circledR}$ pour élever le pH du liquide gastrique. 